\title{
The Rat Genome Contains a p53 Pseudogene: Detection of a Processed Pseudogene Using PCR
}

\author{
Janis E. Hulla
}

Pacific Northwest Laboratory, Richland, Washington 99352

The p53 gene is the most frequently mutated gene in human cancer. Our investigation of this gene in radiation-induced tumors led to the discovery of a processed pseudogene in the rat genome. We amplified eight coding exons of the p53 gene using rat liver DNA as template, and, in each case, one major amplification product was apparent on agarose gels. When we selected primers to amplify fragments containing more than one exon, two major products were apparent. In each case, the size of the larger amplification product was consistent with that of the expected p53 fragment. The sizes of the shorter amplification products suggested that these fragments are ampllfled from a processed p53 pseudogene. When the blotted fragments were probed with sequences internal to the amplification primers, both the gene and putative pseudogene fragments were seen. Sequences of the shorter coamplicons have high homology with the p53 CDNA and cross intron splice junctions. These findings suggest that the rat genome contains a processed p53 pseudogene. The data demonstrate the usefulness of the polymerase chain reaction for revealing processed pseudogenes, and suggest that the pseudogene can be used as an internal control when amplifying the rat p53 gene.
$\mathbf{M}$ utations, deletions, and rearrangements of the p53 gene have been found in a variety of human tumors. ${ }^{(1-10)}$ It now appears that p53 is the most frequently mutated gene in human cancers. ${ }^{(11)}$ Increasing evidence suggests that aberrant expression can result in either a gain of transforming

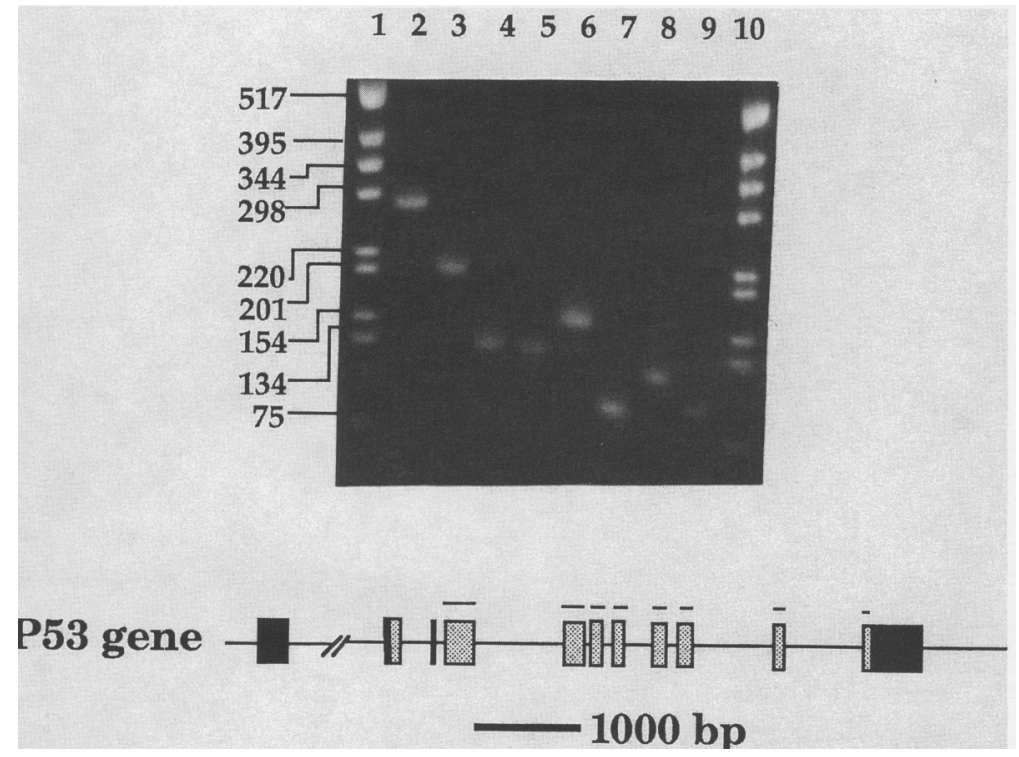

FIGURE 1 A single fragment is amplified when PCR primers flank only one exon of the rat p53 gene. Regions of the gene amplified are indicated by lines on the gene structure diagram. Amplification products were separated electrophoretically using a $2 \%$ agarose gel and stained with ethidium bromide. The table below outlines the contents of each lane along with the expected and apparent sizes of the amplified fragments. Lanes 1 and 10 contain molecular size markers. Predicted molecular sizes are based on the structures of the mouse and human p53 genes. Sizes are given in numbers of base pairs. Sizes of the fragments observed on the gel are estimates based on the resolution of the markers. The sequences of the PCR primers are shown in Table 1.

\begin{tabular}{lcc}
\hline LANE & $\begin{array}{c}\text { PRIMERS } \\
\text { FLANK EXONS }\end{array}$ & $\begin{array}{c}\text { SIZE } \\
\text { (PREDICTED/OBSERVED) }\end{array}$ \\
\hline 2 & 4 & $291 / 290$ \\
3 & 5 & $204 / 200$ \\
4 & 6 & $133 / 130$ \\
5 & 7 & $131 / 130$ \\
6 & 8 & $155 / 150$ \\
7 & 9 & $95 / 100$ \\
8 & 10 & $128 / 130$ \\
9 & 11 & $102 / 100$ \\
\hline
\end{tabular}


potential or a loss of tumor suppressing activity. $(12,13)$ We are investigating the role of p53 in radiation-induced tumors. In the process of using the polymerase chain reaction (PCR) to amplify this gene, we uncovered evidence of a processed p53 pseudogene in the rat genome. Processed pseudogenes arise through a mechanism whereby a spliced mRNA is reversetranscribed and subsequently inserted into the genome. ${ }^{(14)}$ Therefore, a processed pseudogene lacks intervening sequences but may contain noncoding exons or $3^{\prime}$ untranslated regions. A p53 pseudogene has previously been characterized from a 3.3-kb fragment of the mouse genome. ${ }^{(15)}$ Both mouse and rat pseudogenes are colinear with the cDNA and possess no introns. The data presented exemplify the potential of PCR to identify processed pseudogenes, and suggest that the pseudogene can be used as an internal control when amplifying fragments of the rat p53 gene.

\section{METHODS}

The gene structure of the rat p53 gene is not reported. We deduced the locations of splice junctions in the rat gene by assuming that the relative positions and sizes of introns are conserved through evolution (Fig. 1 ).(16) PCR primers were synthesized to have sequences identical to the rat cDNA at the beginning and end of the putative exons. ${ }^{(17)}$ The PCR primers were $17-$ to 23-mers consisting of the cDNA sequences flanking sites considered most likely to be splice junctions (Table 1). We used an Applied Biosystems Inc. (Foster City, California) model 380A synthesizer. Some oligonucleotides were synthesized to contain an amine group on the $5^{\prime}$ end, and Aminolink II (Applied Biosystems Inc.) was used for these terminal additions. The linked oligonucleotides were subsequently biotinylated by adding 50-fold excess of NHS-LC-Biotin II (Pierce Chemical Co., Rockford, Illinois) according to a previously published procedure. ${ }^{(18)}$ Excess biotin was removed by spin dialysis.

Amplification reactions used genomic rat liver DNA as template extracted with an Applied Biosystems' model 340A nucleic acid extractor; Taq DNA polymerase, reaction buffer, and
Table 1. PCR primer sequences.

\begin{tabular}{|c|c|}
\hline exon & upstream sequence \\
\hline 2 & ATGGAGGATTCACAGTCGGATAT \\
\hline 4 & CCACCACAGCGACAGGGT \\
\hline 5 & TACTCAATTТСССТСАAТАA \\
\hline 6 & GCCTGGCTCСТССССАA \\
\hline 7 & GTCGGCTCCGACTATACCACTATC \\
\hline 8 & TGGGAATCTTCTGGGACGGG \\
\hline 9 & CACTGCCCACCAGCACAAGC \\
\hline 10 & ATCCGTGGGCGTGAGCGCTTC \\
\hline 11 & CTACCCGAAGACCAAGAAG \\
\hline exon & downstream sequence \\
\hline 4 & CGTGCACATAACAGACTTGG \\
\hline 5 & CGTCACCATCAGAGCAACG \\
\hline 6 & CTCAGGTGGCTCATACGGTAC \\
\hline 7 & CTGGAGTCTTCCAGCGTG \\
\hline 8 & СTCTCTTTGCACTCCCTGGGGGC \\
\hline 9 & CTTAAGGGTGAAATATTCTCCATC \\
\hline 10 & CTGGAGTGAGCCCTGCT \\
\hline 11 & GTCTGAGTCAGGCCCCA \\
\hline
\end{tabular}

nucle-oside triphosphates were from Perkin-Elmer Cetus (Norwalk, Connecticut). All reactions used a final concentration of $0.2 \mu \mathrm{M}$ for each primer and $1 \mu \mathrm{g}$ of template DNA. Each assay consisted of 35 cycles of $94^{\circ} \mathrm{C}$ for $1 \mathrm{~min}, 58^{\circ} \mathrm{C}$ for $1 \mathrm{~min}$, and $72^{\circ} \mathrm{C}$ for $1 \mathrm{~min}$ or $1.5 \mathrm{~min}$ for fragments larger than $1000 \mathrm{bp}$. To generate template for sequence analysis, a PCR fragment tentatively identified as pseudogene was isolated from a gel and used as template for a second amplification. A biotinylated primer was incorporated at this step to facilitate isolation of single-stranded sequencing template. All amplifications included negative controls consisting of amplification cocktail and sterile deionized water added in lieu of template DNA.

For sequencing, single-stranded DNA was isolated from PCR assays with strepavidin-coated magnetic beads (Dynal Inc., Great Neck, New York) according to the manufacturer's recommendations. Sequenase Version 2 (United States Biochemical, Cleveland, Ohio) was used for sequencing by the dideoxy method. ${ }^{(19)}$ Both strands were sequenced using overlapping fragments of the pseudogene as templates.

\section{RESULTS}

We effectively amplified eight of the individual coding exons using freshly isolated rat liver DNA as template (Fig. 1). The identities of the bands were confirmed by probing with 15-base sequences located internal to the primers. We also amplified larger fragments to include intervening sequences within the most highly conserved region of the gene (Fig. 2). ${ }^{(16)}$ Two major bands are apparent when primers flank more than one exon. Molecular sizes are consistent with the deduced gene structure. The larger bands amplify from the p53 gene. The shorter bands apparently amplify from a processed pseudogene. Their sizes are 


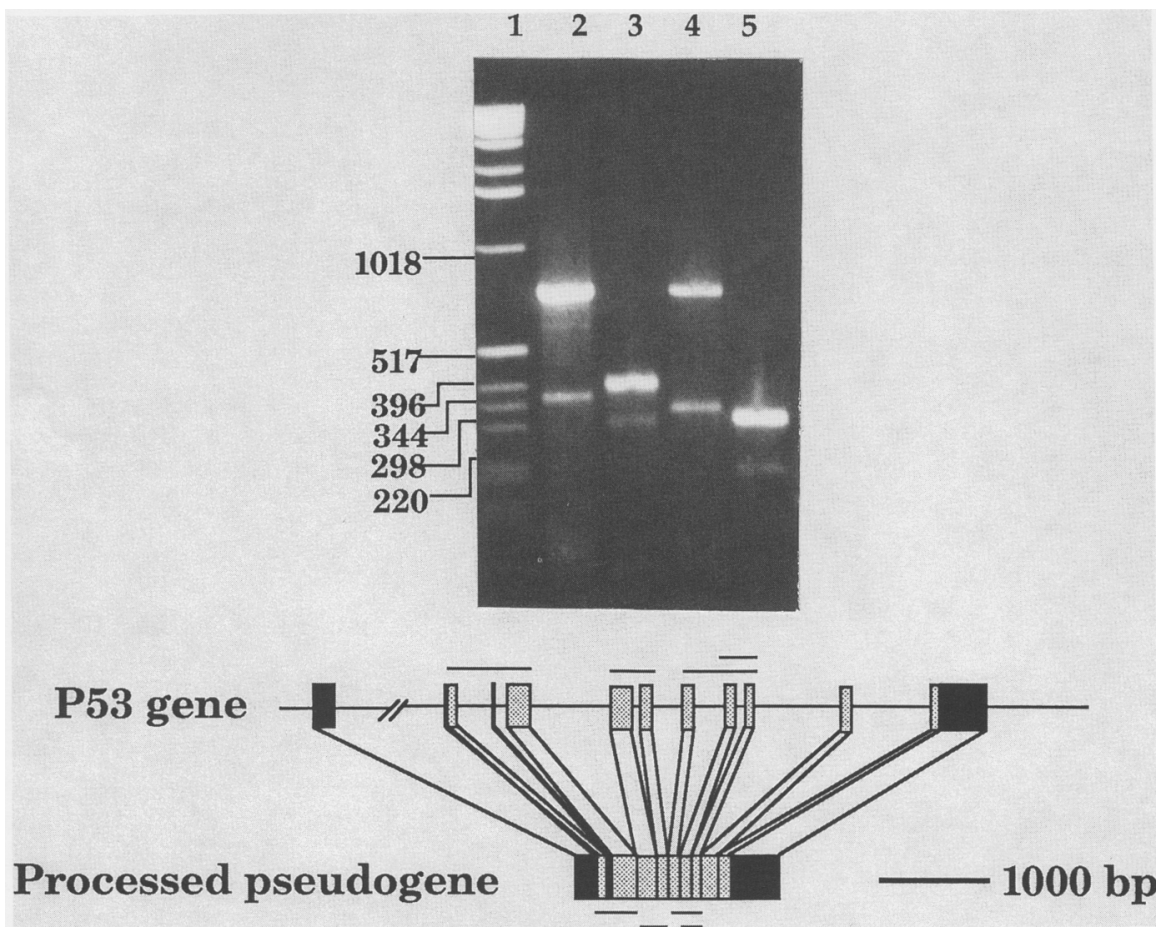

FICURE 2 Two major products are amplified by primers that flank more than one exon of the rat p53 gene. Regions of the gene and pseudogene amplified are indicated by lines on the gene structure graphic. Amplification products were separated electrophoretically on a $1.5 \%$ agarose gel and stained with ethidium bromide. The table below outlines the contents of each lane along with the expected and observed sizes of the amplified fragments. Lane 1 contains molecular size markers. Predicted molecular sizes are based on the structures of the mouse and human p53 genes. Sizes given are in numbers of base pairs. Fragment sizes observed are estimates based on the resolution of the markers. The sequences of the PCR primers are shown in Table 1.

\begin{tabular}{lccc}
\hline Lane & $\begin{array}{c}\text { Primers } \\
\text { flank exons }\end{array}$ & $\begin{array}{c}\text { Gene size } \\
\text { (predicted/observed) }\end{array}$ & $\begin{array}{c}\text { Pseudogene size } \\
\text { (predicted/observed) }\end{array}$ \\
\hline 2 & 2 and 4 & $749 / 750$ & $389 / 375$ \\
3 & 5 and 6 & $397 / 396$ & $317 / 320$ \\
4 & 7 and 9 & $741 / 750$ & $341 / 340$ \\
5 & 8 and 9 & $310 / 320$ & $230 / 225$ \\
\hline
\end{tabular}

consistent with what is expected from a cDNA-like template. The identities of the paired amplification products were confirmed by blotting the fragments and probing with radiolabeled oligonucleotides (Fig. 3). We sequenced approximately 900 bases of the putative pseudogene corresponding to a cDNA region coding for exons 2-9. Comparisons of sequence homology between the rat p53 pseudogene and cDNA are displayed in Table 2.

\section{DISCUSSION}

When p53 PCR primers flank more than one exon, fragments of two sizes are amplified from rat genomic DNA.
The sizes of these fragments are consistent with an evolutionarily conserved gene structure. The data suggest that the shorter fragment amplifies from a processed p53 pseudogene present in the rat genome. Sequences of the putative pseudogene fragments confirm their identities. Each of the pseudogene fragments shown in Figure 2 shares high homology with rat p53 cDNA. Additionally, each fragment contains sequence that crossed intron splice junctions. The rat pseudogene probably arose by reverse transcription of p53 mRNA with subsequent insertion into the genome. It is most likely that this event occurred in the genome of a rodent ancestor of mouse and rat since the mouse also has a processed pseudogene. (15)

We are now taking advantage of the pseudogene's sequence homology with the p53 gene. The pseudogene is providing us with an internal control as we screen for gene aberrations. This is made possible because the same set of primers amplify both gene and pseudogene. By including at least one intron, gene fragments are distinguished from the smaller pseudogene fragment as shown in Figure 2. If the gene contains a deletion or mutation in at least one of the priming sites, it is not amplified. A corresponding aberration in the pseudogene would be extremely rare, therefore the pseudogene amplifies. Under these conditions, there is no need to amplify a second gene as often done to assure the integrity of the template DNA.

These data highlight some important considerations for using PCR to detect genetic aberrations. Since the individual exons of the p53 gene are not distinguished from pseudogene amplicons (Fig. 1), alternative primer sites must be selected to assure gene/pseudogene specificity. Additionally, our findings emphasize the need to eliminate all contaminating DNA when analyzing mRNA by RT-PCR. This is particularly important when processed pseudogene sequences closely resemble the cDNA of the functional gene as they do in the rat p53 gene. ${ }^{(20)}$

\section{ACKNOWLEDGMENTS}

We thank Dr. Richard Schneider for his careful review and comment, and $\mathrm{Mr}$. Chris Poindexter for his fine technical support. This work was supported by the U.S. Department of Energy under Contract No. DE-AC06 1830.

By acceptance of this article, the publisher and/or recipient acknowledge the U.S. Government's right to retain a nonexclusive, royalty-free license in and to any copyright covering this paper.

\section{REFERENCES}

1. Nigro, J.M., S.J. Baker, A.C. Preisinger, J.M. Jessup, R. Hostetter, K. Cleary, S.H. Bigner, N. Davidson, S. Baylin, P. Deville, et al. 1989. Mutations in the p53 gene occur in diverse human tumour types. Nature 342: 705-708. 


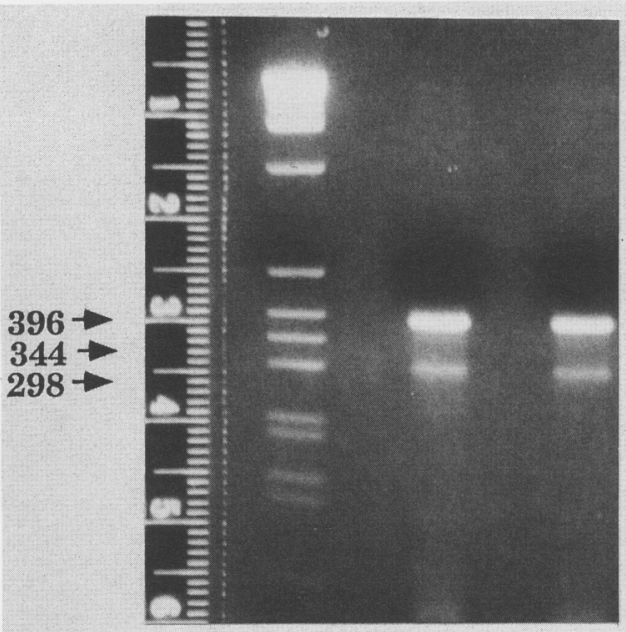

Agarose Gel

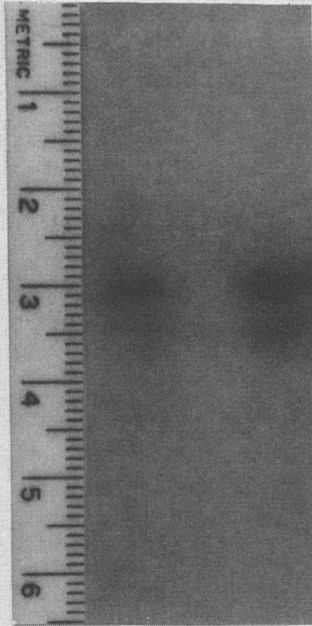

Autoradiograph
FICURE 3 Both the putative gene and pseudogene fragments are positive with p53 sequence probes. Primers flanking exons 5 and 6 were used to amplify the rat p53 gene and putative pseudogene fragments. (Left) The amplification products were separated by electrophoresis on a $1.5 \%$ agarose gel and stained with ethidium bromide. (Lane 1) Molecular weight markers; (lanes 2 and 3) amplified gene and pseudogene fragments. Molecular size is given in numbers of base pairs. The gel was blotted to nylon membrane and probed with a radiolabeled oligonucleotide having sequence complimentary to an internal stretch of exon 5. (Right) The autoradiograph shows that both fragments contain the complementary exon 5 sequence.
2. Shirasawa, S., K. Urabe, Y. Yanagawa, K. Toshitani, T. Iwama, and T. Sasazuki. 1991. p53 gene mutations in colorectal tumors from patients with familial polyposis coli. Cancer Res. 51: 2874-2878.

3. Hollstein, M., D. Sidransky, B. Vogelstein, and C.C. Harris, 1991. p53 mutations in human cancers. Science 253: 49-53.

4. Harris, A.L. 1990. Mutant p53-the commonest genetic abnormality in human cancer. J. Pathol. 162: 5-6.

5. Cheng, J. and M. Haas. 1990. Frequent mutations in the p53 tumor suppressor gene in human leukemia t-cell lines. Mol. Cell. Biol. 10: 55025509.

6. Chiba, I., T. Takahashi, M.M. Nau, D. D'Amico, D.T. Curiel, T. Misudomi, D.L. Buchhagen, D. Carbone, S. Piantadoir, H. Koga, et al. 1990.
Mutations in the p53 gene are frequent in primary, resected nonsmall cell lung cancer. Lung Cancer Study Group. Oncogene 5: 1603-1610.

7. Burmer, G.C., D.A. Crispin, V.R. Kolli, R.C. Haggitt, B.G. Kulander, C.E. Rubin, and P.S. Rabinovitch. 1991. Frequent loss of a p53 allele in carcinomas and their precursors in ulcerative colitis. Cancer Commun. 3: 167-172.

8. Takahashi, T., M.M. Nau, I. Chiba, M.J. Birrer, R.K. Rosenberg, M. Vinocour, M. Levitt, H. Pass, A.F. Gazdar, and J.D. Minna. 1989. P53: A frequent target for genetic abnormalities in lung cancer. Science 246: 491-494.

9. Tamura, G., T. Kihana, K. Nomura, M. Terada, T. Sugimura, and S. Hirohashi. 1991. Detection of frequent p53 gene mutations in primary
TABLE 2 Sequence Homology Between the Putative Rat p53 Pseudogene and cDNA

\begin{tabular}{lccc}
\hline Exons & cDNA location & Bases sequenced & $\begin{array}{c}\text { Percent } \\
\text { homology }\end{array}$ \\
\hline $2-4$ & $24-392$ & 345 & 87 \\
$5-6$ & $393-689$ & 271 & 90 \\
$7-9$ & $689-1010$ & 292 & 88 \\
\hline
\end{tabular}

Received December 17, 1991; accepted in revised form February 19, 1992. gastric cancer by cell sorting and polymerase chain reaction singlestrand conformation polymorphism analysis. Cancer Res. 51: 3056-3058.

10. Munroe, D.G., J.W. Peacock, and S. Benchimol. 1990. Inactivation of the cellular p53 gene is a common feature of friend virus-induced erythroleukemia: Relationship of inactivation to dominant transforming alleles. Mol. Cell. Biol. 10: 3307-3313.

11. Weinberg, R.A. 1991. Tumor suppressor genes. Science 254: 1138-1146.

12. Halevy, O., D. Michalovitz, and M. Oren. 1990. Different tumor-derived p53 mutants exhibit distinct biological activities. Science 250: 113-116.

13. Michalovitz, D., O. Halevy, and $M$. Oren. 1991. p53 mutations: Gains or losses? J. Cell. Biochem. 45: 22-29.

14. Lewin, B.. 1990. Structural genes evolve in families. In Genes IV, pp. 497-517. Oxford University Press, New York.

15. Zakout-Houri, R., M. Oren, B. Bienz, V. Lavie, S. Hazum, and D. Givol. 1983. A single gene and a pseudogene for the cellular tumor antigen p53. Nature 306: 594-597.

16. Soussi, T., C. de Fromentel, and P. May. 1990. Structural aspects of the P53 protein in relation to gene evolution. Oncogene 5: 945-952.

17. Soussi, T., C. de Fromentel, C. Breuognot, and E. May. 1988. Nucleotide sequence of a cDNA encoding the rat p53 nuclear oncoprotein. Nucleic Acids Res. 16: 11384.

18. Levenson, C. and C.-A. Chang. 1990. Nonisotopically labeled probes and primers. In PCR protocols: A guide to methods and applications (eds. M.A. Innis, D. Gelfand J.J. Sninsky, and T.J. White), pp. 99-112. Academic Press, San Diego.

19. Sanger, F. and S.C. Niklen A.R. 1977. DNA sequencing with chain-terminating inhibitors. Proc. Natl. Acad. Sci. 74: 5463-5467.

20. Menon, R.S., Y.-F. Chang, J. St. Clair, and R.G. Ham. 1991. RT-PCR artifacts from processed pseudogenes. $P C R$ Methods Applic. 1: 70-71. 


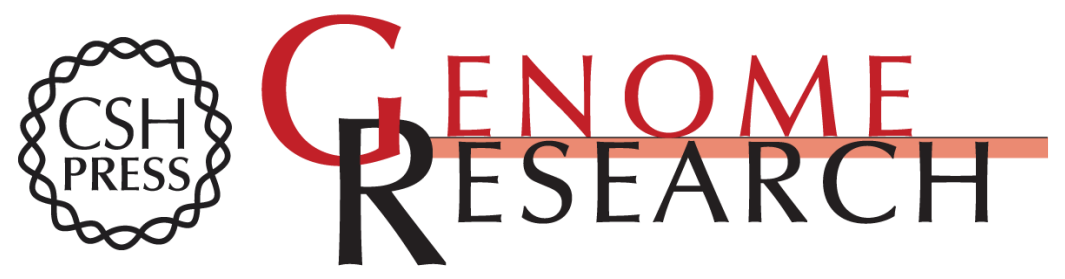

\section{The rat genome contains a p53 pseudogene: detection of a processed pseudogene using PCR.}

J E Hulla

Genome Res. 1992 1: 251-254

Access the most recent version at doi:10.1101/gr.1.4.251

References This article cites 18 articles, 9 of which can be accessed free at:

http://genome.cshlp.org/content/1/4/251.full.html\#ref-list-1

\section{License}

Email Alerting Receive free email alerts when new articles cite this article - sign up in the box at the Service top right corner of the article or click here.

\section{Affordable, Accurate Sequencing.}

To subscribe to Genome Research go to: https://genome.cshlp.org/subscriptions 